\title{
Deteksi Hiperkolesterolemia pada Masyarakat Kota Siak Sri Inderapura
}

\section{Detection of Hypercholesterolemia in Siak Sri Inderapura Community}

Ismawati ${ }^{*}$
Imelda Tresia Pardede ${ }^{2}$
1Department of Biochemsitry,
Universitas Riau, Pekanbaru, Riau,
Indonesia
2Department of Nutrition, Universitas
Riau, Pekanbaru, Riau, Indonesia
"email: ismawati75@yahoo.com
Kata Kunci
Hiperkolesterolemia
Masyarakat
Kota Siak Sri Inderapura
Keywords:
Hypercholesterolemia
Community
Siak Sri Inderapura
Received: November 2019
Pccepted: March 2020
Pulished: June 2020

\begin{abstract}
Abstrak
Penyakit jantung koroner (PJK) adalah suatu kelainan akibat proses aterosklerosis pada arteri koronaria yang mengakibatkan gangguan aliran darah ke otot jantung. Berbagai upaya telah dilakukan untuk mengendalikan PJK tetapi belum memberikan hasil optimal. Salah satu langkah dasar pengendalian ialah dengan melakukan skrining kesehatan yaitu pemeriksaan kolesterol darah. Tujuan kegiatan pengabdian ini adalah meningkatkan pengendalian faktor resiko PJK dengan melakukan deteksi hiperkolesterolemia sehingga diharapkan dapat menurunkan insiden PJK. Sosialisasi kegiatan dilakukan dengan bekerjasama dengan RSUD Siak dan IDI cabang Siak. Calon peserta pengabdian melakukan pendaftaran secara online dan mengisi data berupa nama, jenis kelamin, usia, alamat, pekerjaan, tinggi badan dan berat badan. Pada hari pelaksanaan kegiatan, dilakukan registrasi ulang peserta. Selanjutnya dilakukan pemeriksaan kolesterol darah dan pemberian edukasi mengenai hiperkolesterolemia dan penatalaksanaannya. Upaya deteksi hiperkolesterolemia serta edukasi pada masyarakat Kota Siak Sri Inderapura ini dilaksanakan pada bulan Agustus 2019 di di Gedung Tengku Maharatu. Pengukuran kadar kolesterol masyarakat dilakukan dengan menggunakan alat pemeriksaan digital. Pada pemeriksaan didapatkan sebagian besar peserta memiliki kadar kolesterol total yang normal yaitu $55,94 \%$, sedangkan hiperkolesterolemia didapatkan pada 26 orang peserta $(44,06 \%)$.
\end{abstract}

\begin{abstract}
Coronary heart disease (CHD) is a disorder caused by the process of atherosclerosis in the coronary arteries which results in disruption of blood flow to the heart muscle. Various attempts have been made to control CHD but have not given optimal results. One of the basic steps in controlling is to do a health screening that is checking blood cholesterol. The purpose of this service activity is to improve the control of CHD risk factors by detecting hypercholesterolemia so that it is expected to reduce the incidence of CHD. The program was carried out in collaboration with Siak District Hospital and Siak branch IDI. Prospective service participants register online and fill in data in the form of the name, gender, age, address, occupation, height, and weight. On the day of the activity, participants were re-registered. Next is a blood cholesterol check and education about hypercholesterolemia and its management. The effort to detect hypercholesterolemia and education in the Sri Inderapura Siak City community was carried out in August 2019 at the Tengku Maharatu Building. Measurement of community cholesterol levels is done by using a digital inspection tool. On examination found that most participants had normal total cholesterol levels which were $55.94 \%$, while hypercholesterolemia was found in 26 participants $(44.06 \%)$.
\end{abstract}




\section{PENDAHULUAN}

Penyakit Kardiovaskuler (PKV) merupakan penyebab kematian utama di banyak negara maju, bahkan di negara berkembang, seperti Indonesia (Martiningsih \& Haris, 2019). Penyakit kardiovaskuler terdiri dari 2 bentuk utama yaitu penyakit jantung koroner (PJK) dan penyakit serebrovaskuler (terutama stroke iskemik) (Khairatunnisa \& Sari, 2017). Penyakit jantung koroner dan stroke masing-masing merupakan penyebab kematian utama $(84,5 \%)$ dan ketiga $(28,2 \%)$ di dunia (Barquera et al., 2015).

Penyakit jantung koroner adalah suatu kelainan akibat proses aterosklerosis pada arteri koronaria yang mengakibatkan gangguan aliran darah ke otot jantung (Mizuno et al., 2011). Faktor risiko aterosklerosis dapat dibedakan menjadi faktor risiko mayor atau utama dan faktor risiko minor. Faktor risiko mayor diantaranya adalah umur, jenis kelamin, keturunan (ras), merokok, hiperkolesterolemia, hipertensi, kurang aktivitas fisik, diabetes mellitus, dan obesitas. Sedangkan yang termasuk faktor risiko minor adalah stress, alkohol, diet dan nutrisi (Ma'rufi \& Rosita, 2014).

Hiperkolesterolemia adalah peningkatan kadar kolesterol di dalam darah. Banyak faktor yang memengaruhi keseimbangan kolesterol di dalam jaringan yang dapat mengakibatkan terjadinya hiperkolesterolemia (Soliman, 2018). Peningkatan kolesterol terjadi karena ambilan lipoprotein yang mengandung kolesterol oleh reseptor LDL, ambilan lipoprotein yang mengandung kolesterol oleh jalur yang tidak diperantarai reseptor, ambilan kolesterol bebas dari lipoprotein yang kaya kolesterol oleh sel membran, sintesis kolesterol, dan hidrolisis ester kolesterol oleh enzim kolesterol ester hidrolase (Daniels et al., 2009). Ambilan kolesterol yang meningkat ini salah satunya disebabkan oleh tingginya konsumsi makanan yang tinggi kolesterol dan lemak jenuh (Blesso \& Fernandez,
2018). Seiring perkembangan zaman dan modernisasi yang terus terjadi menyebabkan perubahan pola dan gaya hidup masyarakat terutama di daerah perkotaan. Perubahan pola dan gaya hidup ini salah satunya ialah dengan banyaknya restoran makanan cepat saji yang menjual makanan mengandung kolesterol tinggi dan sedikit mengandung nutrisi (Yani, 2015).

Peningkatan insiden PJK akan memberikan beban kesakitan, kecacatan dan beban sosial ekonomi bagi keluarga penderita, masyarakat, dan negara. Berbagai upaya telah dilakukan untuk mengendalikan PJK tetapi belum memberikan hasil optimal. Salah satu langkah dasar pengendalian ialah dengan melakukan skrining kesehatan yaitu pemeriksaan kolesterol darah. Hiperkolesterolemia pada tahap tertentu belum menunjukkan gejala, sehingga satu-satunya cara adalah untuk mendeteksi hiperkolesterolemia adalah dengan melakukan pemeriksaan darah (Lina \& Saraswati, 2020; Gaziano et al., 2010).

Upaya skrining hiperkolesterolemia membutuhkan partisipasi dari semua pihak, baik pemerintah, swasta maupun masyarakat. Partisipasi ini perlu untuk mengendalikan hiperkolesterolemia sehingga insiden PJK dapat ditekan (Lina \& Saraswati, 2019). Sebagian besar masyarakat enggan untuk melakukan skrining hiperkolesterolemia karena berbagai sebab, mulai dari aspek biaya, keterjangkauan ke lokasi pemeriksaan, keterbatasan sarana prasarana maupun aspek waktu (Syauqy \& Fitri, 2019).

Berdasarkan latar belakang tersebut, para pengabdi bermaksud melakukan pemeriksaan kadar kolesterol darah pada masyarakat kota SiakSri Inderapura. Melalui kegiatan ini, diharapkan dapat menurunkan insiden PJK sehingga meningkatkan kualitas hidup masyarakat Kota Siak Sri Inderapura, dan masyarakat Indonesia pada umumnya. 


\section{METODOLOGI}

Calon peserta pengabdian melakukan pendaftaran secara online dan mengisi data berupa nama, jenis kelamin, usia, alamat, pekerjaan, tinggi badan dan berat badan. Sosialisasi kegiatan dilakukan dengan bekerjasama dengan RSUD Siak dan IDI cabang Siak. Pada hari pelaksanaan kegiatan, dilakukan registrasi ulang peserta. Selanjutnya dilakukan pemeriksaan kolesterol darah dan pemberian edukasi mengenai hiperkolesterolemia dan penatalaksanaannya.

Upaya deteksi hiperkolesterolemia serta edukasi pada masyarakat Kota Siak Sri Inderapura ini dilaksanakan pada bulan Agustus 2019 di di Gedung Tengku Maharatu. Pengukuran kadar kolesterol masyarakat dilakukan dengan menggunakan alat pemeriksaan digital dengan merk easy touch. Masyarakat yang telah diperiksa kadar kolesterolnya diberikan kertas hasil pemeriksaan untuk konsultasi bersama pakar secara dua arah.

Pelaksana kegiatan pengabdian masyarakat ini adalah tim yang terdiri atas dosen Fakultas Kedokteran Universitas Riau (FK UNRI), dokter umum alumni FK UNRI dan mahasiswa FK UNRI yang berjumlah enam orang. Tujuan kegiatan pengabdian ini adalah meningkatkan pengendalian faktor resiko PJK dengan melakukan deteksi hiperkolesterolemia sehingga diharapkan dapat menurunkan insiden PJK.

\section{HASIL DAN PEMBAHASAN}

Pemeriksaan kolesterol darah dan edukasi dilakukan terhadap 59 orang masyarakat Kota Siak Sri Inderapura. Peserta sebagian besar berjenis kelamin Perempuan $(93,2 \%)$, sedangkan hanya sedikit yang berjenis laki-laki. Sebagian besar peserta berusia antara 20-30 tahun (42,37\%) seperti ditunjukkan pada Tabel I, sementara sebagian besar peserta $(35,59 \%)$ memiliki indeks massa tubuh (IMT) normal seperti ditunjukkan pada Tabel II.
Tabel I. Distribusi peserta berdasarkan usia

\begin{tabular}{llcc}
\hline No & Usia (Tahun) & Frekuensi (n) & Persentase (\%) \\
\hline 1 & $<20$ & 6 & 10,17 \\
2 & $20-30$ & 25 & 42,37 \\
3 & $31-40$ & 11 & 18,64 \\
4 & $41-50$ & 13 & 22,03 \\
5 & $51-60$ & 3 & 5,08 \\
6 & $>60$ & 1 & 1,71 \\
\hline
\end{tabular}

Tabel II. Distribusi peserta berdasarkan IMT

\begin{tabular}{llcc}
\hline No & Klasifikasi IMT & Frekuensi (n) & Persentase (\%) \\
\hline 1 & Underweight & 10 & 16,95 \\
2 & Normal & 21 & 35,59 \\
3 & Overweight & 8 & 13,56 \\
4 & Obesitas I & 16 & 27,12 \\
5 & Obesitas II & 4 & 6,78 \\
\hline
\end{tabular}

Pada pemeriksaan didapatkan sebagian besar peserta memiliki kadar kolesterol total yang normal yaitu $55,94 \%$, sedangkan kondisi hiperkolesterolemia didapatkan pada 26 orang peserta $(44,06 \%)$ seperti yang ditunjukkan pada Tabel III. Hasil ini lebih tinggi dibandingkan persentase hiperkolesterolemia pada masyarakat Indonesia secara umum yaitu 25,23\% (Soleha, 2012) serta masyarakat Kota Jambi pada Tahun 2016 yaitu 33,33\% (Charles et al., 2016) dan pada Tahun 2018 yaitu 14,28\% (Syauqy \& Fitri, 2019). Hal ini kemungkinan karena pada kegiatan ini 47,46\% peserta memiliki IMT kategori overweight dan obesitas. Uji ANOVA menunjukkan perbedaan yang bermakna kadar kolesterol berdasarkan IMT. Hasil ini sejalan dengan penelitian Soleha (2012) yang mendapatkan hubungan yang bermakna antara IMT dan hiperkolesterolemia. Dokumentasi kegiatan Pengabdian disajikan pada Gambar 1.

Tabel III. Distribusi peserta berdasarkan kadar kolesterol

\begin{tabular}{llcc}
\hline No & \multicolumn{1}{c}{$\begin{array}{c}\text { Kadar kolesterol } \\
\text { darah total }\end{array}$} & $\begin{array}{c}\text { Frekuensi } \\
\text { (n) }\end{array}$ & $\begin{array}{c}\text { Persentase } \\
\text { (\%) }\end{array}$ \\
\hline 1 & Hiperkolesterolemia & 26 & 44,06 \\
2 & $(>200 \mathrm{mg} / \mathrm{dl})$ & 33 & 55,94 \\
& Normal $(<200 \mathrm{mg} / \mathrm{dl})$ & & \\
\hline
\end{tabular}




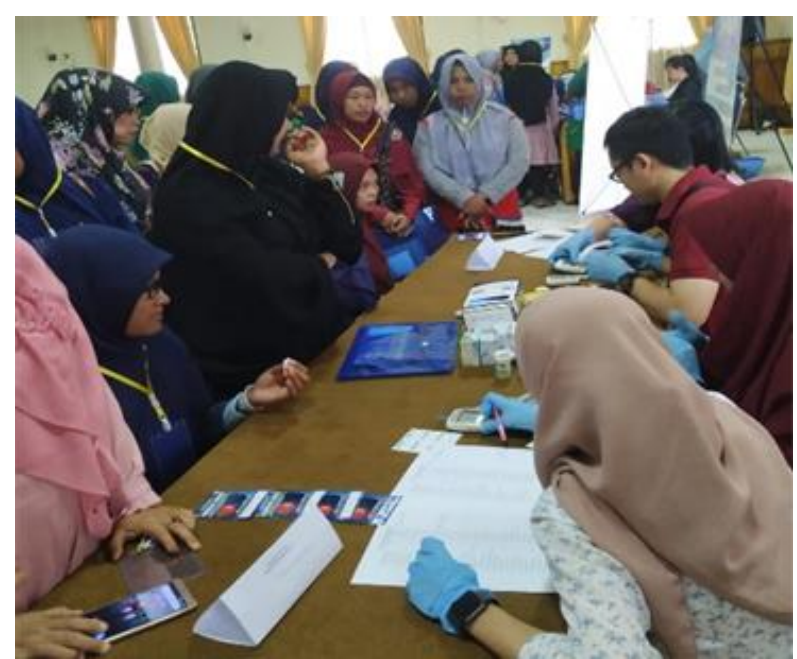

Gambar 1. Pemeriksaan kolesterol darah

\section{KESIMPULAN}

Kegiatan pemeriksaan kolesterol darah dan edukasi mengenai hiperkolesterolemia dan penatalaksanaannya sangat bermanfaat untuk pencegahan penyakit jantung koroner. Kegiatan ini perlu untuk mengendalikan hiperkolesterolemia sehingga insiden PJK dapat ditekan. Kegiatan ini dapat dilakukan secara berkesinambungan sebagai upaya pencegahan PJK.

\section{UCAPAN TERIMA KASIH}

Penulis mengucapkan terimakasih kepada Fakultas Kedokteran Universitas Riau yang telah memberi bantuan dana dalam kegiatan pengabdian masyarakat ini, IDI Cabang Siak, RSUD, Siak serta alumni dan mahasiswa Fakultas Kedokteran Universitas Riau yang telah membantu pelaksanaan kegiatan pengabdian masyarakat.

\section{REFERENSI}

Barquera, S., Pedroza-Tobias, A., Medina, C., Hernandez-Barrera, L., Bibbins-Domingo, K., Lozano, R., Moran, A.E. 2015. Global Overview of the Epidemiology of Atherosclerotic Cardiovascular Disease. Archives of Medical Research. 46(5):328-338. https://doi.org/10.1016/j.arcmed.2015.06.006
Blesso, C.N., Fernandez, M.L. 2018. Dietary Cholesterol, Serum Lipids, and Heart Disease: Are Eggs Working for or Against You? Nutrients. 10(4):426.

https://dx.doi.org/10.3390/nu10040426

Charles, A.S., Wulandari, P.S., Maria, I. 2016. Pemeriksaan kadar kolesterol dan tekanan darah pada masyarakat Kota Jambi sebagai skrining awal penyakit jantung koroner. Jurnal Pengabdian pada Masyarakat. 31(4):18-20.

Daniels, T.F., Killinger, K.M., Michal, J.J., Wright, R.W., Jiang, Z. 2009. Lipoproteins, cholesterol homeostasis and cardiac health. International Journal of Biological Sciences. 5(5):474-488. https://dx.doi.org/10.7150/ijbs.5.474

Gaziano, T.A., Bitton, A., Anand, S., Abrahams-Gessel, S., Murphy, A. 2010. Growing Epidemic of Coronary Heart Disease in Low- and MiddleIncome Countries. Current Problems in Cardiology. 35(2):72-115. https://dx.doi.org/10.1016/j.cpcardiol.2009.1 0.002

Khairatunnisa, Sari, D.M. 2017. Faktor Risiko Yang Berhubungan Dengan Kejadian Stroke Pada Pasien Di RSU H. Sahudin Kutacane Kabupaten Aceh Tenggara. JUMANTIK (Jurnal Ilmiah Penelitian Kesehatan). 2(1):60-70. http://dx.doi.org/10.30829/jumantik.v2i1.96 2

Lina, N., Saraswati, D. 2020. Deteksi Dini Penyakit Jantung Koroner di Desa Kalimanggis dan Madiasari Kabupaten Tasikmalaya. Warta LPM. 23(1):45-53. https://doi.org/10.23917/warta.v23i1.9019

Lina, N., Saraswati, D. 2019. Deteksi Dini Penyakit Jantung Koroner Di Pos Pembinaan Terpadu Penyakit Tidak Menular (Posbindu PTM). Jurnal Kesehatan Komunitas Indonesia. 15(2):93104.

Martiningsih, M., Haris, A. 2019. Risiko Penyakit Kardiovaskuler pada Peserta Program Pengelolaan Penyakit Kronis (Prolanis) di Puskesmas Kota Bima: Korelasinya dengan Ankle Brachial Index dan Obesitas. Jurnal Keperawatan Indonesia. 22(3):200-208. http:/ /dx.doi.org/10.7454/jki.v22i3.880

Ma'rufi, R., Rosita, L. 2014. Hubungan Dislipidemia Dan Kejadian Penyakit Jantung Koroner. JKKI: 
Jurnal Kedokteran dan Kesehatan Indonesia. 6(1):47-53.

https://doi.org/10.20885/JKKI.Vol6.Iss1.Art

7

Mizuno, Y., Jacob, R.F., Mason, R.P. 2011. Inflammation and the Development of Atherosclerosis. Journal of Atherosclerosis and Thrombosis. 18(5):351-358.

https://doi.org/10.5551/jat.7591

Soleha, M. 2012. Kadar Kolesterol Tinggi Dan FaktorFaktor Yang Berpengaruh Terhadap Kadar Kolesterol Darah. Jurnal Biotek Medisiana Indonesia.

1(2):85-92. https://doi.org/10.22435/jbmi.v1i2.1531

Soliman, G.A. 2018. Dietary Cholesterol and the Lack of Evidence in Cardiovascular Disease. Nutrients. 10(6):780.

https:/ /dx.doi.org/10.3390/nu10060780

Syauqy, A., Fitri, A.D. 2019. Pemeriksaan Kadar Kolesterol Darah Pada Masyarakat Umum Yang Berkunjung Ke Taman Jomblo Kota Jambi Sebagai Skrining Awal Hiperkolesterolemia. Medical Dedication (Medic): Jurnal Pengabdian kepada Masyarakat FKIK UINJA. 2(1):1-4.

Yani, M. 2015. Mengendalikan Kadar Kolesterol Pada Hiperkolesterolemia. JORPRES (Jurnal Olahraga Prestasi). 11(2):1-7. https://doi.org/10.21831/jorpres.v11i2.5749 